\title{
Article \\ Utilization of Clay Materials as Support for Aspergillus japonicus Lipase: An Eco-Friendly Approach
}

\author{
Daniela Remonatto ${ }^{1}$ (D) Bárbara Ribeiro Ferrari ${ }^{1}$, Juliana Cristina Bassan ${ }^{1}$, Cassamo Ussemane Mussagy ${ }^{1,2}(\mathbb{D}$, \\ Valéria de Carvalho Santos-Ebinuma ${ }^{1, *}$ and Ariela Veloso de Paula ${ }^{1, *}$
}

1 Department of Engineering of Bioprocesses and Biotechnology, School of Pharmaceutical Sciences, São Paulo State University (UNESP), Araraquara 14800-903, Brazil; d.remonatto@unesp.br (D.R.); barbaraferrari30@gmail.com (B.R.F.); juliana.bassan@unesp.br (J.C.B.); cassamo.mussagy@unesp.br (C.U.M.)

2 Department of Pharmaceutical-Biochemical Technology, School of Pharmaceutical Sciences, University of São Paulo, Ribeirão Preto 14000-000, Brazil

* Correspondence: valeria.ebinuma@unesp.br (V.d.C.S.-E.); ariela.veloso@unesp.br (A.V.d.P.); Tel.: +55-16-3301-4647 (V.d.C.S.-E.)

Citation: Remonatto, D.; Ferrari, B.R.; Bassan, J.C.; Mussagy, C.U.; de Carvalho Santos-Ebinuma, V.; Veloso de Paula, A. Utilization of Clay Materials as Support for Aspergillus japonicus Lipase: An Eco-Friendly Approach. Catalysts 2021, 11, 1173. https://doi.org/10.3390/ catal11101173

Academic Editors: Chia-Hung Kuo, Chun-Yung Huang, Chwen-Jen Shieh and Cheng-Di Dong

Received: 29 August 2021

Accepted: 26 September 2021

Published: 28 September 2021

Publisher's Note: MDPI stays neutral with regard to jurisdictional claims in published maps and institutional affiliations.

Copyright: (c) 2021 by the authors. Licensee MDPI, Basel, Switzerland This article is an open access article distributed under the terms and conditions of the Creative Commons Attribution (CC BY) license (https:// creativecommons.org/licenses/by/ $4.0 /)$
Abstract: Lipase is an important group of biocatalysts, which combines versatility and specificity, and can catalyze several reactions when applied in a high amount of industrial processes. In this study, the lipase produced by Aspergillus japonicus under submerged cultivation, was immobilized by physical adsorption, using clay supports, namely, diatomite, vermiculite, montmorillonite KSF (MKSF) and kaolinite. Besides, the immobilized and free enzyme was characterized, regarding $\mathrm{pH}$, temperature and kinetic parameters. The most promising clay support was MKSF that presented $69.47 \%$ immobilization yield and hydrolytic activity higher than the other conditions studied (270.7 $\mathrm{U} \mathrm{g}^{-1}$ ). The derivative produced with MKSF showed high stability at $\mathrm{pH}$ and temperature, keeping $100 \%$ of its activity throughout $12 \mathrm{~h}$ of incubation in the $\mathrm{pH}$ ranges between 4.0 and 9.0 and at a temperature from 30 to $50{ }^{\circ} \mathrm{C}$. In addition, the immobilized lipase on MKSF support showed an improvement in the catalytic performance. The study shows the potential of using clays as support to immobilized lipolytic enzymes by adsorption method, which is a simple and cost-effective process.

Keywords: lipase; immobilization; Aspergillus japonicus; montmorillonite KSF

\section{Introduction}

Lipases (also triacylglycerol ester hydrolase) [EC 3.1.1.3] are enzymes that hydrolyze ester linkages of triglycerides [1,2]. Since these enzymes present large structural and functional versatility, they are of greatest importance in industrial sector to be applied in the food, pharmaceutical, detergent, textile, biodiesel production, cosmetic, among others $[3,4]$. Considering the high number of lipase applications, the microbial lipase market was valued at $\$ 400.6$ million in 2017 , with expectations to achieve a $\$ 590$ million in 2023 at a Compound annual growth rate (CAGR) of $6.8 \%$ [5]. Over the last years, the growing interest in large-scale production of more natural enzymes, i.e., microbial lipase, has increased due to its outstanding advantages, viz., high stability, high productivity yield, no seasonal restrictions, use of agro-waste/residues as feedstock and low-cost production as compared to other sources (animal or vegetable) $[2,3,6]$.

In nature, a large number of microorganisms have been described as natural lipase producers, among these, filamentous fungi stand out due to their ability to biosynthesize extracellular lipases with improved catalytic characteristics in relation to stability and specificity [7-10]. The filamentous fungi from the genera Aspergillus, Rhizopus, Penicillium, Mucor, and Fusarium are commonly used for the commercial production of lipases [10], with special notoriety on A. niger, Humicola lanuginosa, Mucor miehei, R. arrhizus, R. delemar, $R$. japonicus, $R$. niveus, and $R$. oryza species [8]. The industrial needs for new microbial sources of lipases with different catalytic characteristics [11] encouraged the search of new 
strains, viz, A. japonicus. In this sense, following the selection of lipase-strain producer, the enzyme immobilization its necessary, as it allows easy control of reaction parameters (flow rate and substrates), reuse of immobilized catalysts and suitable chemical, mechanical and thermal stability $[3,12]$.

A wide range of physical and chemical techniques have been used over the last few years for lipases immobilization purpose, cf., adsorption, encapsulation and entrapment, confinement, covalent binding and cross-linking [12], physical adsorption (lipases immobilized by hydrophobic interactions) [13-15] followed by covalent binding being the main methods used [16]. It should be noted that the choice of support for immobilization is crucial for the catalytic effectiveness of an enzyme, and in general, the support is considered ideal when it has good biocompatibility, high physical and chemical stability, presence of multiple enzyme-support binding points and low cost [17]. Inorganic clays are low-cost supports, with high adsorption capacity, environmentally friendly properties and renewable abundance [18,19]. Among those, clay minerals such as, diatomite, vermiculite, montmorillonite KSF and kaolinite are good examples of supports for enzyme immobilization [20], due to the unique physicochemical characteristics, viz, high thermal and chemical stability, mechanical strength, charge density (excellent ion exchange and adsorption capacity), relative hydrophobicity-hydrophilicity, high surface area, microbial resistance, environmental sustainability and economically viable [18,21-30].

The adsorption of enzymes to clay miners depends on a series of physical and chemical characteristics of the clays, as well as the structural characteristics of the enzymes, ionic strength of the adsorbent solution and the interaction between these factors [22,31]. Smectite clays such as montmorillonite have a large surface area and pore volume, useful characteristics in the adsorption process, the enzymes can be adsorbed on both the internal and external surface of the mineral [21,31,32]. These materials have been successful used to immobilize invertase [33,34], $\alpha$-amylase [34], glucoamylase [34], lipase [22,35-41], inulinase [42], pectinase [25], phytase [21] and rhynchophorol [30].

Following these promising reports, the aim of this study was focused on the production by submerged culture and immobilization of Aspergillus japonicus (A. japonicus) lipase using different supports (diatomite, vermiculite, montmorillonite KSF and kaolinite) by physical adsorption procedure. As a final test to validate the industrial potential of A. japonicus lipase, the kinetic properties of enzymatic derivatives and its free form were evaluated and compared.

\section{Results and Discussion}

\subsection{Production of Lipase by A. japonicus}

As aforementioned, microbial lipases, $c f .$, Aspergillus-based lipases present great potential to be used in many industrial fields, to produce detergents, biodiesel, bread, functional foods, among others [43]. There are few reports about the microbial production of lipase by A. japonicus in the literature [44-50]. However, among the works found, it is clear that the kinetic parameters $\left(K_{M}\right.$ and $\left.V_{\max }\right)$ are directly affected by the composition of nutritional media, substrate used in the enzymatic assay, type of cultivation (solid or submerged) and several processual parameters, i.e., $\mathrm{pH}$, temperature and agitation [44-50]. The ideal temperature to achieve high lipase production yields generally ranges from 30 to $50{ }^{\circ} \mathrm{C}$ [45-50] and $\mathrm{pH} 6.0$ to 8.5 which are considered optimal for $A$. japonicus growth and therefore the successful production of lipase [45-50].

In this work, the production of extracellular lipase by A. japonicus using olive oil as substrate was evaluated, and the obtained enzymatic extract clearly demonstrate the ability of microorganism to hydrolyze triacylglycerols, achieving, $20.42 \mathrm{U} \mathrm{ml}^{-1}$ and $934.958 \mathrm{U} \mathrm{mg}^{-1}$ of lipase hydrolytic activity and specific activity, respectively. These results are in accordance with those (20.6 $\left.\mathrm{U} \mathrm{ml}^{-1}\right)$ obtained by Karanam et al. [44] in the hydrolysis of p-nitrophenyl palmitate (pNPP) by a lipase preparation using a genetically modified strain of A. japonicus MTCC 1975. Evaluating the lipase production by A. japonicus LAB01 in medium supplemented with sunflower oil $\left(1 \% \mathrm{w} \mathrm{w}^{-1}\right)$, at $\mathrm{pH} 6.0$, Souza et al. [47] achieved 
$28.04 \mathrm{U} \mathrm{ml}^{-1}$ on pNPP hydrolysis. Likewise, purified lipase obtained by A. japonicus produced in cultivation media containing malt extract, also showed specific activity of $36.83 \mathrm{U} \mathrm{mg}^{-1}$, using Jatropha oil as substrate [45]. So, the filamentous fungi A. japonicus has the ability to metabolize different substrate to produce lipolytic enzymes with application in several biotechnological processes.

\subsection{Characterization of Free A. japonicus Lipase}

2.2.1. $\mathrm{pH}$ Effects on Enzyme Activity and Stability

The $\mathrm{pH}$ has great effect on the lipase activity, being essential to define this parameter for the efficient characterization of the $A$. japonicus lipase produced. The activity profiles and stability of the free lipases at $\mathrm{pH} 3.0$ to 10.0 using different buffers at the same concentration $(0.1 \mathrm{M})$ were measured (Figure 1a).
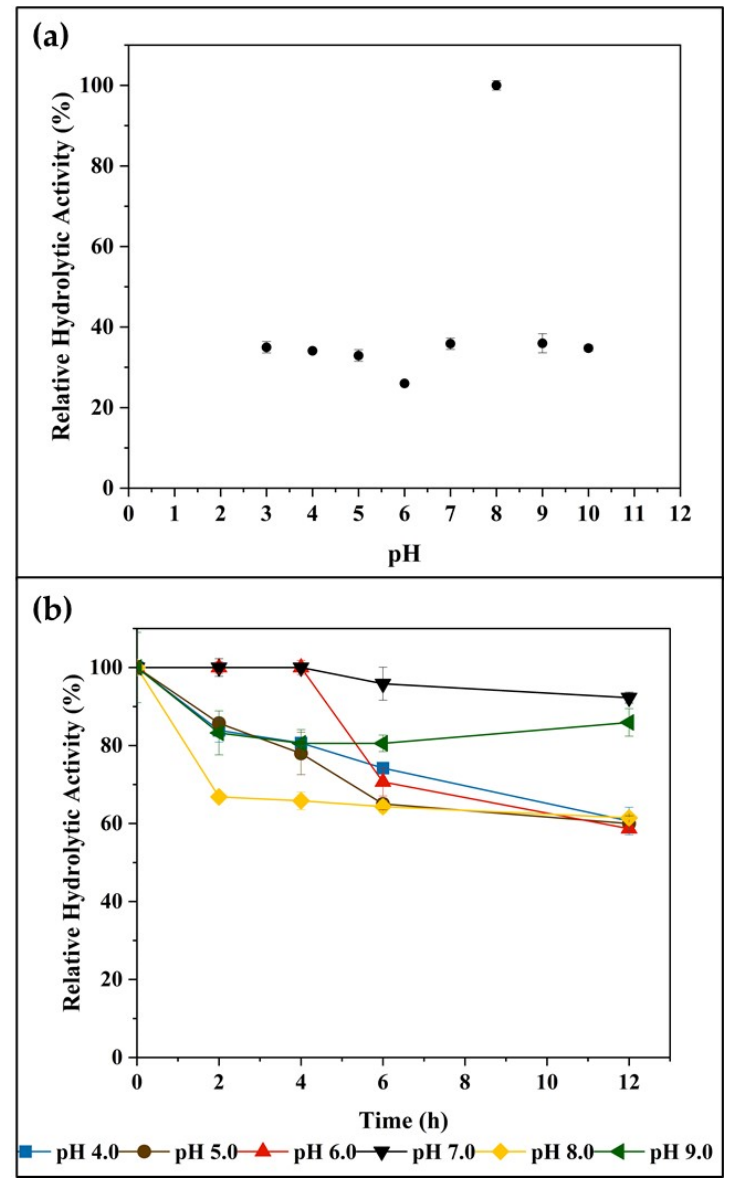

Figure 1. Characterization of lipase from $A$. japonicus in relation to optimal $\mathrm{pH}$ (a) and $\mathrm{pH}$ stability through time (until $12 \mathrm{~h}$ of incubation) (b). These experiments were performed at $30{ }^{\circ} \mathrm{C}$. In the optimal $\mathrm{pH}, 100 \%$ is related to the highest hydrolytic activity achieved. In the $\mathrm{pH}$ stability studies, the initial activity obtained at time zero to each $\mathrm{pH}$ was considered $100 \%$ (different values for each $\mathrm{pH}$ values). The error bars represent the standard deviation of triplicates.

As depicted in Figure 1a the hydrolytic activity of the free lipase is highest in the $\mathrm{pH}$ 8.0. It is well-known that lipases show their activity at alkaline $\mathrm{pH}$ as result of a change in the ionization state of amino acid that varies with $\mathrm{pH}$, and consequently affect the active site and the enzyme conformation [51-53]. The optimum $\mathrm{pH}$ found in this study for the activity of A. japonicus lipase are similar to results reported in literature using the same microbial specie, in which maximum lipase activities were obtained around $\mathrm{pH} 6.7$ to 7.9 [45] and 8.5 [47]. 
The $\mathrm{pH}$ stability of lipases produced through submerged cultivation of $A$. japonicus was initially assessed at $\mathrm{pH} 4.0$ to 9.0 (Figure 1b). In this particular case, the initial activity value (time zero) obtained for each $\mathrm{pH}$ (from 4.0 to 9.0 ) was defined as $100 \%$. As shown in Figure 1b, at pH 7.0 lipase showed high stability value, preserving $92 \%$ of its original hydrolytic activity after $12 \mathrm{~h}$ of reaction. This result is in accordance with previous studies [54] in which lipase produced by Aspergillus sp., achieved high $\mathrm{pH}$ stability at 7.0 after $48 \mathrm{~h}$ of incubation. In this work, interesting results were also observed at $\mathrm{pH} 9.0$ (Figure $1 \mathrm{~b}$ ), in which a slight decrease of $\sim 20 \%$ after $4 \mathrm{~h}$ was detected maintaining the original activity $(\sim 80 \%)$ until the end of $12 \mathrm{~h}$ of incubation. The present results demonstrate that the microbial enzyme under study is an alkaline lipase, that maintain the stability under basic conditions and can be used in several industries for the production of detergents, for example [47].

\subsubsection{Temperature Effects on Enzyme Activity and Stability}

The effect of temperature (at $\mathrm{pH}$ 8.0, optimal $\mathrm{pH}$ conditions) on the lipase activity was also evaluated, and the enzyme demonstrate activity in a wide range of temperatures $\left(20-60{ }^{\circ} \mathrm{C}\right.$ ), with maximum activity value reached at $30^{\circ} \mathrm{C}$ (Figure 2a). The results were similar to those of A. niger strain MTCC 872 [55] and A. niger [56]. According to the literature, several microbial lipases produced by Aspergillus species exhibit optimal temperature close to $37^{\circ} \mathrm{C}[51,54,57,58]$.

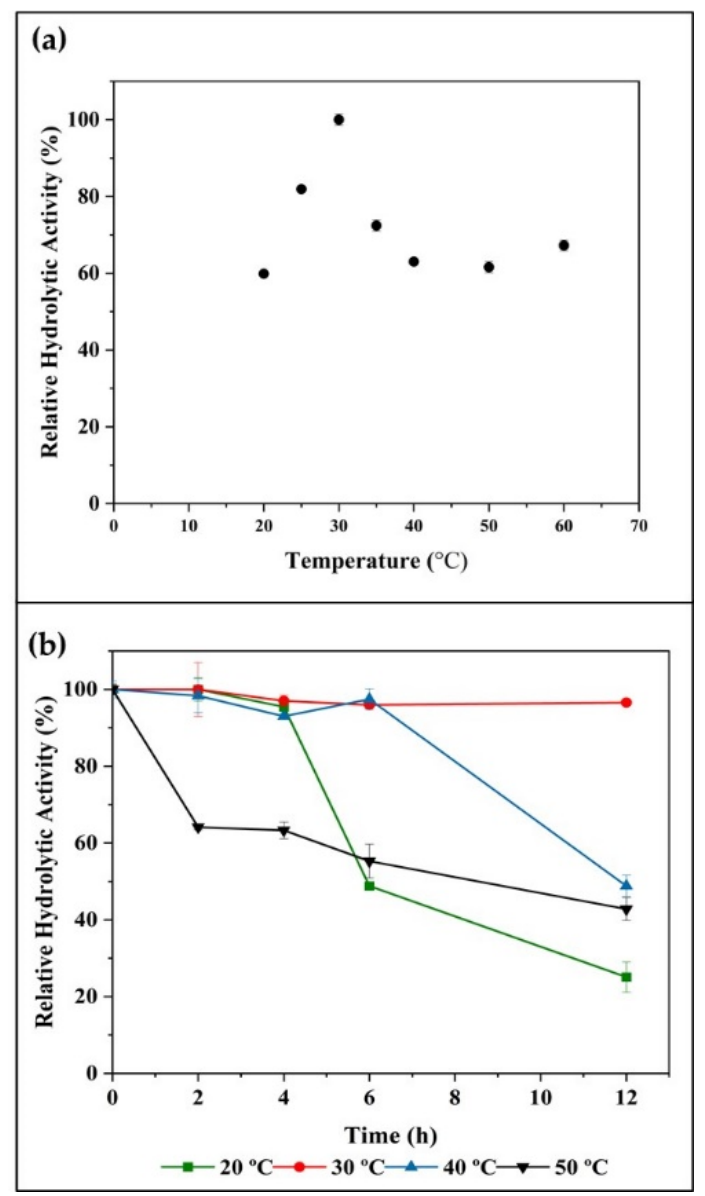

Figure 2. Characterization of $A$. japonicus lipase in relation to optimal temperature (a) and temperature stability through time (until $12 \mathrm{~h}$ of incubation) (b). These experiments were performed at $\mathrm{pH}$ 8.0. In the optimal temperature, $100 \%$ is related to the highest hydrolytic activity achieved. In the temperature stability studies, the initial activity obtained at time zero to each temperature was considered $100 \%$ (different values for each temperature values). The error bars represent the standard deviation of triplicates. 
The thermostability of lipase was studied by incubating it at different temperatures: $20{ }^{\circ} \mathrm{C}, 30^{\circ} \mathrm{C}, 40{ }^{\circ} \mathrm{C}$ and $50{ }^{\circ} \mathrm{C}$, at $\mathrm{pH} 8.0$ for $12 \mathrm{~h}$. Note that, the $100 \%$ is referred to the initial activity value obtained at time zero for each temperature evaluated. As depicted in Figure $2 \mathrm{~b}$, at $30^{\circ} \mathrm{C}$, the enzyme was stable for the $12 \mathrm{~h}$ of study and retained $100 \%$ of its activity. However, when the enzyme was incubated at $20{ }^{\circ} \mathrm{C}$ and $40{ }^{\circ} \mathrm{C}$ the enzyme maintained $95.45 \%$ and $93.1 \%$ of its activity after $4 \mathrm{~h}$ of incubation. After this period, at $20{ }^{\circ} \mathrm{C}$ a pronounced loss of enzyme activity was observed, reaching around of $50 \%$ of activity after $12 \mathrm{~h}$ of incubation. Interestingly, at $20^{\circ} \mathrm{C}$, the activity loss initiated from $4 \mathrm{~h}$ of incubation, and after $12 \mathrm{~h}$, it was achieved an activity loss around $75 \%$. For $50{ }^{\circ} \mathrm{C}$, lipase lost about $40 \%$ of its relative activity after $2 \mathrm{~h}$ and at the end of $12 \mathrm{~h}$ of incubation time, a decrease in the hydrolytic activity (75-60\%) was perceived, indicating a possible lipase denaturation caused by prolonged exposure to temperatures $\left(20,40\right.$ and $\left.50{ }^{\circ} \mathrm{C}\right)[54,59]$. According to these results, $30^{\circ} \mathrm{C}$ in not only the temperature of optimal enzyme activity but also the one that keeps the lipase stability. From the literature, it is known that the formation of the enzyme-substrate complex is impacted by the temperature since it has influence in the number of collisions between the enzyme and substrate [54,59]. However, high temperatures, 40 and $50{ }^{\circ} \mathrm{C}$ in the case of $A$. japonicus lipase, may promote the protein denaturation which explains the low activity measured at these conditions after $12 \mathrm{~h}$ of incubation.

It was also performed the polyacrylamide gel electrophoretic of culture media containing the enzyme. According to Mala and Takeuchi [60], the molecular weight of microbial lipase is from 20 to $60 \mathrm{kDa}$. From the electrophoresis data, it can be seen that the culture media containing the $A$. japonicus lipase has a single band with a relative molecular weight of $25 \mathrm{kDa}$ on SDS-PAGE gel (Figure 3), demonstrating that the obtained A. japonicus lipase has a single subunit. A. japonicus lipase with molecular weight of $25 \mathrm{kDa}$ was reported by Souza et. al [47] while the same specie produced an enzyme with molecular weight of $43 \mathrm{kDa}$ using Jatropha oil as substrate [45].

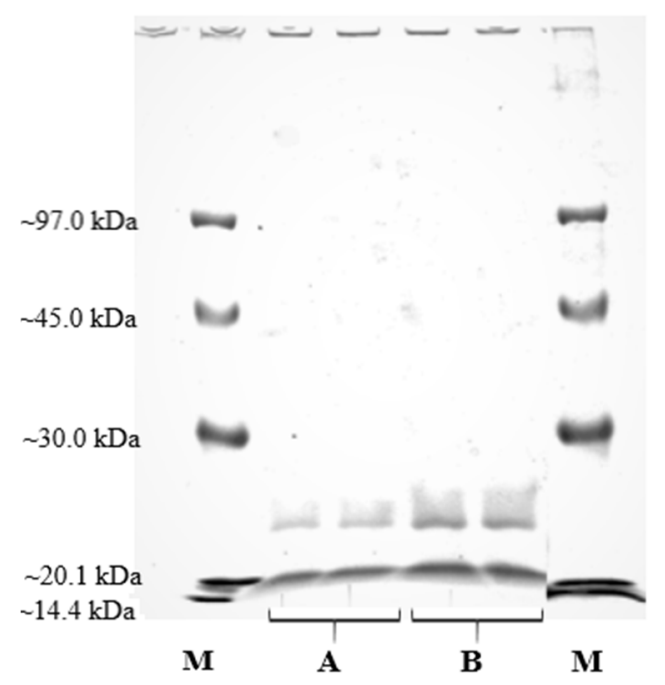

Figure 3. SDS-Page of $A$. japonicus lipase produced by submerged culture. The columns represent: M: molecular weight markers (14.4-97 kDa). A: culture media containing $A$. japonicus lipase at $155.2 \mathrm{mg} \mathrm{mL}^{-1}$; B: culture media containing A. japonicus lipase at $257.2 \mathrm{mg} \mathrm{mL}^{-1}$.

\subsection{Immobilization of A. japonicus Lipase Using Different Supports}

The immobilization of lipase was performed by physical adsorption using four different supports, namely, diatomite, vermiculite, montmorillonite KSF (MKSF) and kaolinite, and in all cases $1 \mathrm{~g}$ of support were suspended in $20 \mathrm{mg} \mathrm{mL}^{-1}$ of protein. The immobilization yield of each derivative was calculated by comparing the protein content of enzymatic solution in the initial and the final immobilization. The results in Figure 4 exhibit the 
hydrolytic activity expressed in $\mathrm{U} \mathrm{g}^{-1}$ and immobilization yield (\%) of A. japonicus lipase immobilized in the above-mentioned supports.



\section{Yield Immobilization UTाA Hydrolytic Activity}

Figure 4. Enzymatic activity and immobilization yield of $A$. japonicus lipase immobilized on the supports: diatomite, vermiculite, montmorillonite KSF (MKSF) and kaolinite by physical adsorption. The error bars represent the standard deviation of triplicates.

As shown in Figure 4 all supports were able to immobilize lipase from A. japonicus, the immobilization yields (\%) and enzymatic activity $\left(\mathrm{U} \mathrm{g}^{-1}\right)$ follow the trend: MKSF (69.47 and 270.7) > kaolinite (68.14 and 75.51) > vermiculite (58.45 and 72.89) > diatomite (7.97 and 10.5). So, the MKSF support presented the highest yield. The hydrolytic activity obtained for lipase immobilization using MKSF $\left(270.7 \mathrm{U} \mathrm{g}^{-1}\right)$ were three-fold more than the obtained using kaolinite $\left(75.51 \mathrm{U} \mathrm{g}^{-1}\right.$ ) with immobilizations yield around $\sim 70 \%$. The adsorption of enzymes in a different types of clay minerals, involves a wide variety of physical and/or chemical interactions, which mainly depend on the nature and type of both compounds. The surfaces of clay minerals may differ mainly due to the presence of the enzyme molecule [61], and even with high immobilization yields, i.e., kaolinite (68.14\%) and vermiculite (58.45\%) (Figure 4), low biocatalyst activity can occur. This behavior usually arises, when the adsorption occurs near to the enzyme active site, hindering the access of substrate molecules, or even due to the diffusion resistance [33].

Similar studies regarding lipases and MKSF, were also reported by Scherer et al. [38], in the immobilization of porcine pancreatic lipase by physical adsorption using MKSF. In this case the immobilization yield reached $38.2 \%$ and high esterification activity were also observed $\left(1400 \mathrm{U} \mathrm{g}^{-1}\right)$ demonstrating the potential of MKSF effective support for use in the immobilization of lipases.

Proteins are usually adsorbed by several interactions such as, cation exchange, electrostatic interactions, van der Waals forces, hydrogen bonds, or by the hydrophobic/hydrophilic moiety present on the clay surface $[31,62,63]$. Often, in protein immobilization using clay supports, protein molecules spontaneously interact with hydrophobic regions [31] and in particular case of the increased activity of lipases in the presence of MKSF (hydrophobic interphases) is known as "interfacial activation" [35,64-66].

In the study developed by Sani et al. [67], the lipase from Rhizopus oryzae was immobilized by physical adsorption on a polypropylene support with additive CAVAMAX ${ }^{\circledR} \mathrm{W} 6$ achieving an increase of $100 \%$ in relative activity after immobilization. According to the authors, the interactions between lipase and support were mostly hydrophobic, the hydropho- 
bic effect resulted in open conformation and interfacial activation of lipase during adsorption, leading to an improvement in the enzymatic activity after immobilization procedure.

Most lipolytic enzymes present on their surface, close to the active site, a helical loop, referred in the literature as a "lid" $[68,69]$. When lipases come into contact with hydrophobic surfaces, the reaction is similar to the way they recognize natural substrates (generally lipids) and the "lid" opens, allowing exposure of the enzyme's active site, a phenomenon called interfacial activation [35,64-66]. In a hydrophobic or non-aqueous environment, the hydrophobic layer triggers the opening of the "lid", allowing the entry of the substrate into the active site, whereas in aqueous environments the lipase remains inactive [70,71]. Thus, the enzymatic activity of the lipases that contain the "lid" is controlled by the cap domain [71,72]. Thus, immobilization process on hydrophobic supports allows the immobilization of the open conformation of the lipase, improving its enzymatic activity, causing the enzyme to hyperactivate [66,73-75]. It is important to highlight that the lipase contains one or more caps in the helix form and that not all lipases undergo interfacial activation [71].

As a result of the interesting immobilization yield and hydrolytic activity obtained with lipase from A. japonicus immobilized with MKSF, this derivative was selected to evaluate the effect of $\mathrm{pH}$ and temperature on activity and stability and the determination of kinetic parameters in the next section.

\subsection{Characterization of A. japonicus Lipase Immobilized on MKSF}

In the previous section, it was shown that the great hydrolytic activity and immobilizations yields of lipase were obtained using MKSF as a support. Therefore, to obtain a better understanding of the impact of the support (MKSF) it is essential to understand the changes occurred in the kinetics parameters, $\mathrm{pH}$ and temperature stability during the lipase immobilization process, as discussed in the next subsections.

\subsubsection{Effect of $\mathrm{pH}$ and Temperature on Immobilized Lipase Activity}

The effect of $\mathrm{pH}$ in the immobilized lipase activity was studied in the range of $\mathrm{pH}$ from 3.0 to 10.0 using different buffers at $0.1 \mathrm{M}$ (Figure 5). The immobilized lipase showed different behaviors of $\mathrm{pH}$ dependence than the free lipase, achieving the optimal $\mathrm{pH}$ at 7.0 and 8.0, with high relative activity of $95.5 \%$ and $100 \%$, respectively (Figure 5a). As also depicted in Figure 5a, the immobilized lipase showed much higher activity than the free enzyme (Figure 1a), and improvements in relation to the hydrolytic activity in the range of $\mathrm{pH} 4.0$ to 10.0 were observed. A similar observation was reported by Tacin et al. [76] using Aspergillus sp. lipase immobilized by octyl-sepharose. In this particular case, the authors suggested that the changes in the optimal $\mathrm{pH}$ of immobilized lipase is directly related to the conformation change of the enzyme molecules after immobilization, making the catalytic site more easily accessible to the ions $\left(\mathrm{H}^{+}\right.$or $\left.\mathrm{OH}^{-}\right)$.

In this set of trials, the initial activity (time zero) defined as $100 \%$, was considered different to each $\mathrm{pH}$ as depicted in Figure 5b. In all evaluated $\mathrm{pH}$ (from 4.0 to 9.0) the immobilized lipase showed great $\mathrm{pH}$ stability, maintaining the catalytic activity $(100 \%)$ for $12 \mathrm{~h}$ of incubation reaction, achieving an improvement (40\%) in pH stability as compared with the free lipase (Figure 1b). A similar extended $\mathrm{pH}$ profile for lipase immobilized on montmorillonite K10 was also reported by Sanjay and Sugunan [33]. The shift in the $\mathrm{pH}$ optimum for lipase immobilized in usually, and as reported by Dong et. al [35], the maximum amount of $\mathrm{H}^{+}$ions in the support surfaces leads to the changes in $\mathrm{pH}$ value on the catalysis microenvironment.

In a study performed by Sanjay and Sugunan [33] to immobilize invertase enzyme using montmorillonite $\mathrm{K} 10$, this process changed the optimal $\mathrm{pH}$ from 5.0 to 6.0. According to the author, negatively charged supports, as montmorillonite K10, changes the optimal $\mathrm{pH}$ due to charge interaction changing the enzyme ionization. 


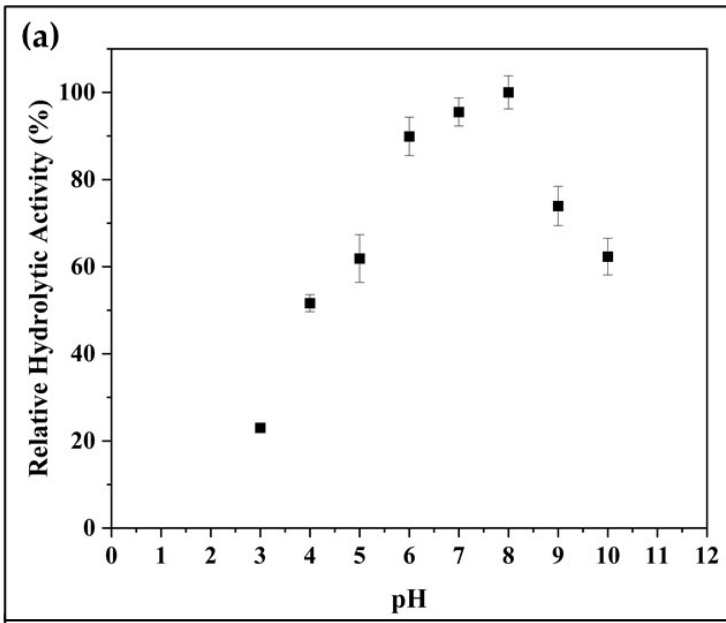

(b)

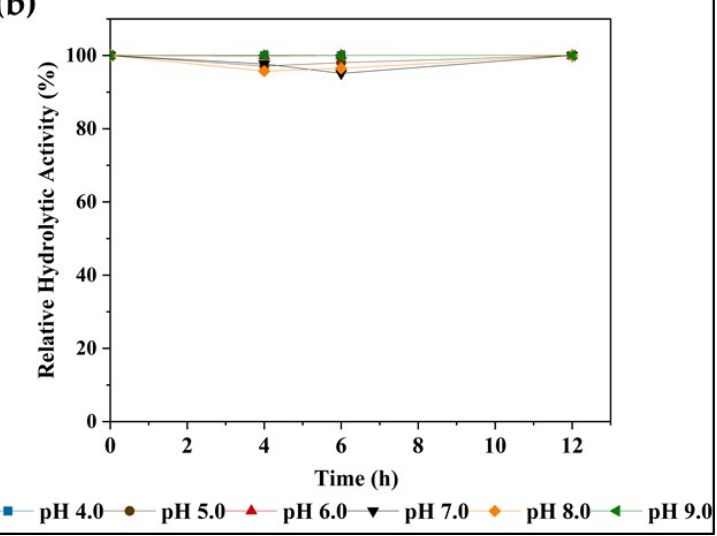

Figure 5. Characterization of A. japonicus lipase immobilized in MKSF support in relation to optimal $\mathrm{pH}$ (a) and $\mathrm{pH}$ stability through time (until $12 \mathrm{~h}$ of incubation) (b). These experiments were performed at $30^{\circ} \mathrm{C}$. In the optimal $\mathrm{pH}, 100 \%$ is related to the highest hydrolytic activity achieved. In the $\mathrm{pH}$ stability studies, the initial activity obtained at time zero to each $\mathrm{pH}$ was considered $100 \%$ (different values for each $\mathrm{pH}$ values). The error bars represent the standard deviation of triplicates.

Additionally, the effect of temperature on the immobilized A. japonicus lipase activities was also investigated in the range of 20 a $60{ }^{\circ} \mathrm{C}$ (Figure 6a). The maximal activity of the immobilized lipase was as high as $30^{\circ} \mathrm{C}$, the same value obtained by the free lipase (Figure 2a). Similar results were found by Zou et. al [41] and Sani et. al. [66] in which the enzymes kept their optimal temperature at $50{ }^{\circ} \mathrm{C}$. However, the immobilized enzymes were more stable in a wide range of temperature as compared with free-enzyme.

Figure $6 \mathrm{~b}$, demonstrates the effect of reaction temperature on the activities of the immobilized lipases within the range of 20,40 and $50{ }^{\circ} \mathrm{C}$ at optimal $\mathrm{pH}(8.0)$, and the initial activity (at time zero) was defined $100 \%$ for each temperature evaluated. As observed, the optimal reaction temperature $\left(30,40\right.$ and $\left.50{ }^{\circ} \mathrm{C}\right)$ of immobilized lipase achieved the $100 \%$ of the original catalytic activity for $12 \mathrm{~h}$ of incubation. On the contrary, with the reaction temperature constantly decreasing to $20^{\circ} \mathrm{C}$, the relative activity of immobilized lipase only maintained $87.1 \%$ of its activity at the end of $12 \mathrm{~h}$. In this set of experiments, it was observed that immobilized $A$. japonicus lipase present much wider temperature endurance range.

The temperature has two-main impacts on the A. japonicus lipase catalytic activity, namely, (i) the thermal energy of substrate (olive oil) is affected by the increasing of temperature that led to the collision of substrate molecules with enzymes and (ii) the increase of temperature can also lead the denaturation of lipase caused by the cleavage of non-covalent bonds [54,59]. In this way, the immobilization process can promote a protection against exposure to high temperature $[37,77]$ and prevent the unfolding of the 
tertiary structure of the enzyme [78]. As cited before, high temperatures can promote the disruption of disulphide bonds and salt bridges (ionic bonds), interactions that maintain the spatial conformation of the enzymes $[79,80]$. Thus, the immobilized enzyme maintained these bonds in the studied temperature range.
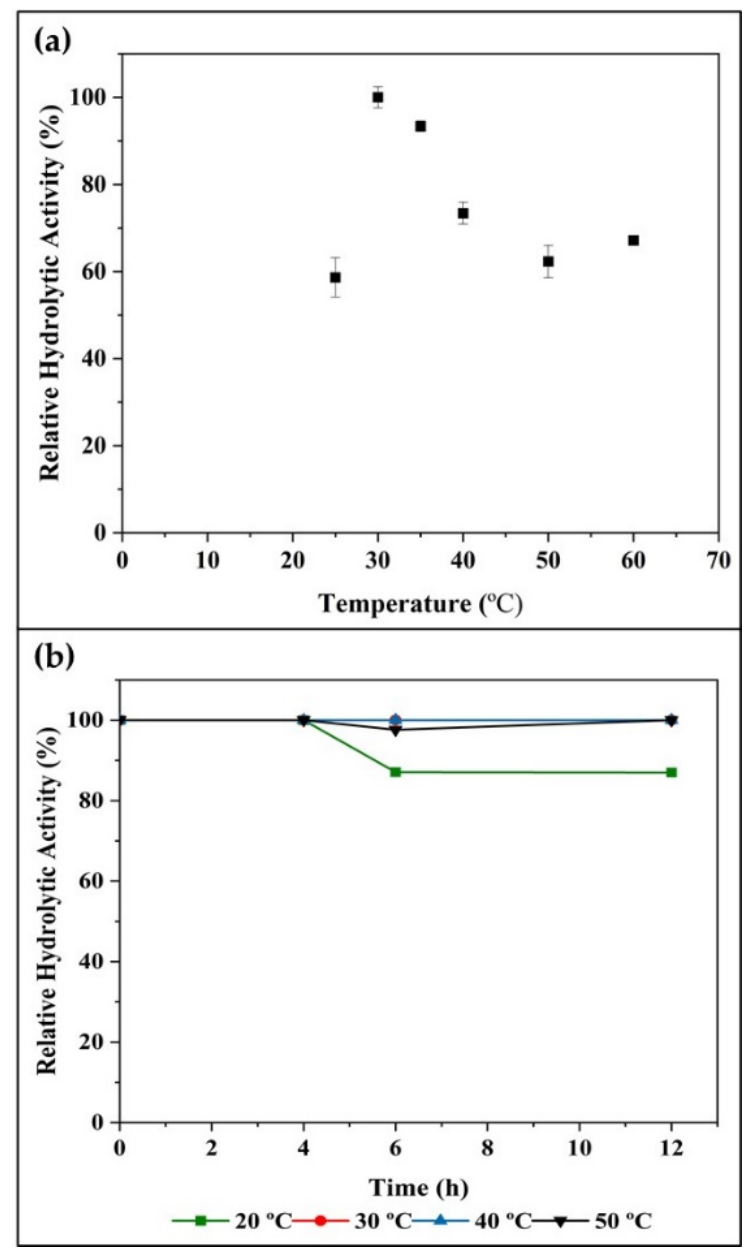

Figure 6. Characterization of $A$. japonicus lipase immobilized in MKSF support in relation to optimal temperature (a) and temperature stability through time (until $12 \mathrm{~h}$ of incubation) (b). These experiments were performed at $\mathrm{pH} 8$ In the optimal $\mathrm{pH}, 100 \%$ is related to the highest hydrolytic activity achieved. In the $\mathrm{pH}$ stability studies, the initial activity obtained at time zero to each $\mathrm{pH}$ was considered $100 \%$ (different values for each temperature values). The error bars represent the standard deviation of triplicates.

Montmorillonite are 2:1 dioctahedral, and are the most commonly used clay mineral as outstanding supports with capability to adsorb enzymes on the external surface (hydrophobic interactions) and intercalated in interlayer space (cation exchange) [61]. The enzymes (e.g., lipases) immobilization by cation exchange, in the support (montmorillonite) interlayer space, provides to the enzyme, more stability, and protection against thermal denaturation [61,81-83]. Thus, the great results concerning the stability (in $\mathrm{pH}$ and temperature), of derivatives immobilized in MKSF may be related to the partial immobilization of A. japonicus lipase by intercalation.

Similar trends were observed by Benamia et. al [37] in a work focused on the identification of natural supports for immobilization of Candida rugosa lipase (CRL). In this work, the immobilized CRL on Maghnite-H exhibited good thermostability over a wide temperature range $\left(30-90^{\circ} \mathrm{C}\right)$ compared to the free one. Tu et. al [40] studied the Yarrawia lipolytica lipase immobilization in chitosan modified with clay (Na-betonite) and the lipase immobilized were more thermostable than the enzyme immobilized in chitosan no-modified and the 
free one and showed more reusability (up to 7 reuses). According to the authors, the incorporation of clay provided a support with greater adsorption capacity and greater rigidity (mechanical resistance), improving its performance. In the studies performed by Morais et al. [84] in the immobilization of Endocellulase and $\beta$-glucosidase in magnetic iron oxide nanoparticles demonstrated that the enzymatic immobilization improved the thermal stability of the biocatalysts, achieving residual activities of $80 \%$ in $72 \mathrm{~h}$ of incubation at $60{ }^{\circ} \mathrm{C}$.

\subsubsection{Kinetic Parameters of Free and Immobilized Lipase}

Apparent kinetic parameters are essential for the selection of enzyme regarding different industrial processes and applications. Kinetic parameters of the free and immobilized lipases were determined in the optimal temperature and $\mathrm{pH}$ conditions $\left(30^{\circ} \mathrm{C}, \mathrm{pH} 8.0\right.$, $200 \mathrm{rpm}$ at $5 \mathrm{~min}$ ), varying only the olive oil (substrate) from 186 to $2604 \mathrm{mM}$ in the reactional media. Through using software Origin 8.0, the Michaelis-Menten constant $\left(K_{M}\right)$ and the initial maximum reaction velocity $\left(V_{\max }\right)$ of the lipase were calculated. The results for free and immobilized lipases are given in the Figure $7 a$ and $b$, respectively.
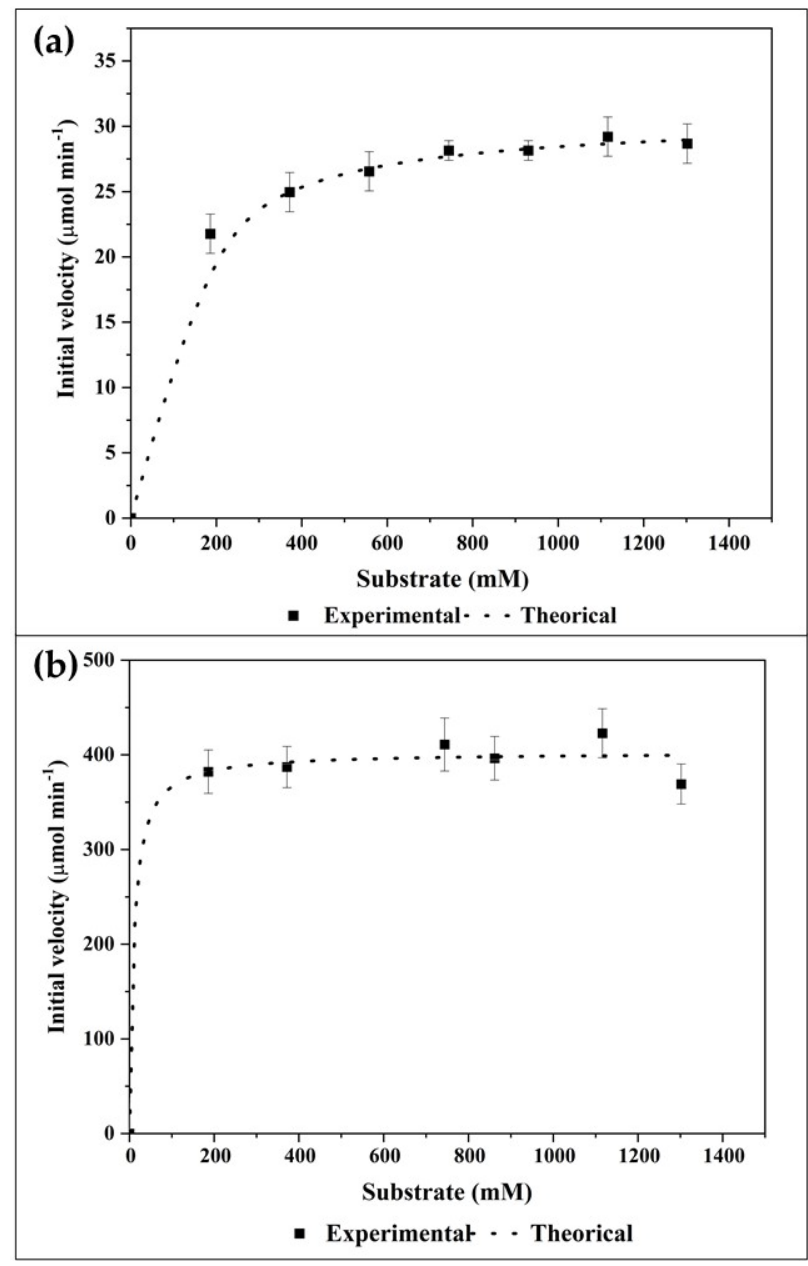

Figure 7. Hyperbolic Michaelis-Menten regression of $A$. japonicus lipase (a) free and (b) immobilized in MKSF support, at different concentration of olive oil substrate at $30{ }^{\circ} \mathrm{C}$ and $\mathrm{pH}$ 8.0. The error bars represent the standard deviation of triplicates.

As observed in Figure 7a the experimental data set fit with the calculated theoretical data, with an $\mathrm{R}^{2}=0.9986$, demonstrating that the produced lipase from $A$. japonicus follows the Michaelis-Menten kinetics. The values of $K_{M}$ and $V_{\max }$ obtained was $79.35 \mathrm{mM}$ and 
$30.71 \mu \mathrm{mol} \mathrm{min}^{-1}$, respectively. In study reported by Bharti et al. [45], lipase produced by other strain of $A$. japonicus also followed the Michaelis-Menten kinetics.

As observed in Figure $7 \mathrm{~b}$, the predicted and experimentally $K_{M}$ value illustrated a correlation of $\mathrm{R}^{2}=0.9849$. The $V_{\max }$ and $K_{M}$ values of immobilized lipase were $402.56 \mu \mathrm{mol} \mathrm{min}{ }^{-1}$ and $9.87 \mathrm{mM}$, respectively. The $K_{M}$ value obtained with the immobilized lipase was 4 times lower than those obtained with free lipase $(79.35 \mathrm{mM})$ (Figure 7a). Note that, the higher $K_{M}$ value suggested the lower affinity between the enzyme and substrate [85], and in this particular work, the low value of the $K_{M}$ in the A. japonicus lipase immobilized MKSF suggested the higher affinity to the substrate in comparison to the free form. The $V_{\max }$ value of immobilized lipase $\left(402.56 \mu \mathrm{mol} \mathrm{min}^{-1}\right)$ was 13 times greater than those obtained with the free one $\left(30.71 \mu \mathrm{mol} \mathrm{min}^{-1}\right)$ (Figure $7 \mathrm{a}$ ) proving that the enzyme activity improved. Moreover, these results suggest that the native lipase conformation was not altered by the immobilization process [34].

Actually, immobilized enzyme in different supports is applied in continuous process in food industry to produce corn syrup, cocoa butter analogues and galacto-oligosaccharides, synthesis of chiral molecules among others [86], in pharmaceutical industry to synthetize chiral molecules [86] and in the chemical industry to produce complex molecules such as chiral amines and herbicides [86]. So, there is a wide range of process that immobilized enzymes can be applied and the results reported in the present work demonstrate that the low cost MKSF is a promising support for $A$. japonicus lipase, and can encourage the scientific community to explore other clays-based substrates for enzymes immobilization, providing a natural and economical support to the industrial application of immobilized enzyme.

\section{Materials and Methods}

\subsection{Material}

Peptone (bacteriological) and Potato Dextrose Agar (PDA) were acquired from Acumedia ${ }^{\circledR}$. Olive oil from Carbonell ${ }^{\circledR}$ (Córdoba, Spain) was obtained in a local market. Kaolinite was purchased from Sigma-Aldrich (St. Louis, MO, USA) and diatomite, vermiculite, montmorillonite KSF, were acquired from Laboratório de Peneiras Moleculares (LABPEMOL) from Federal University of Rio Grande do Norte (UFRN). All the other reagents were of analytical grade and used as received.

\subsection{Microorganism}

Aspergillus japonicus DPUA1727 was kindly provided by the Culture Collection of Federal University of Amazonas, DPUA, AM, Brazil. The A. japonicus preserved in distilled water was reactivated in PDA $\left(39.0 \mathrm{~g} \mathrm{~L}^{-1}\right.$ agar potato dextrose composed of dehydrated Potato Infusion and Dextrose) supplemented with yeast extract $\left(0.5 \% \mathrm{w} \mathrm{v}^{-1}\right)$ and maintained at $30{ }^{\circ} \mathrm{C}$ for 7 days. Afterward, the cultures were kept in the refrigerator at $4{ }^{\circ} \mathrm{C}$ and defined as a stock culture for the whole work.

\subsection{Production of Aspergillus japonicus Lipase by Submerged Culture}

Initially, lipase was produced using a methodology described by Tacin et al. [54]. Briefly, the inoculum was prepared in PDA plates, and the cultures were maintained at the same reactivation conditions. Following, 5 mycelial agar discs ( $8 \mathrm{~mm}$ diameter) of microorganism were inoculated in Erlenmeyer flasks $(250 \mathrm{~mL})$ containing $50 \mathrm{~mL}$ of culture medium composed of ( $\mathrm{g} \mathrm{L}^{-1}$, in deionized water): peptone (40); olive oil (1.6); $\mathrm{MgSO}_{4} \cdot 7 \mathrm{H}_{2} \mathrm{O}$ (1.2); $\mathrm{KH}_{2} \mathrm{PO}_{4}$ (2.0) and $\mathrm{NH}_{4} \mathrm{NO}_{3}$ (2.0). The experiments were performed in triplicate and the initial $\mathrm{pH}$ of the culture medium was adjusted to 7.0. Cells were grown for $72 \mathrm{~h}$ at $30^{\circ} \mathrm{C}$ and $150 \mathrm{rpm}$ in an orbital shaker New Ethics, model 521/2DE (Piracicaba, $\mathrm{SP}$, Brazil). After the cultivation, A. japonicus biomass was separated from the fermented supernatant containing the enzyme by conventional filtration using a filter paper Whatman $80 \mathrm{~g} \mathrm{~m}^{-2}$ (Maidstone, Kent, England). The cell-free filtrate containing lipases, was used to measure the hydrolytic enzyme activity and total proteins, according methodologies described in Sections 3.4.1 and 3.4.2, respectively. 


\subsection{Analytical Methods}

\subsubsection{Determination of Hydrolytic Enzyme Activity}

The hydrolytic enzyme activity was carried out using an emulsion containing olive oil $50 \% \mathrm{w} \mathrm{w}^{-1}$ and gum Arabic $7 \% \mathrm{w} \mathrm{w}^{-1}$ [87]. The unit of hydrolytic enzyme activity was calculated as the amount of enzyme required to hydrolyze $1 \mu \mathrm{mol}$ of fatty acid per minute of reaction. The activity was expressed in $\mu \mathrm{mol} \mathrm{mL}^{-1} \mathrm{~min}^{-1}\left(\mathrm{U} \mathrm{mL}^{-1}\right)$ for lipase in free form and in $\mu \mathrm{mol} \mathrm{g}^{-1} \mathrm{~min}^{-1}\left(\mathrm{U} \mathrm{g}^{-1}\right)$ for immobilized derivatives.

\subsubsection{Determination of Protein Content}

The concentration of total proteins was determined by the method described by Bradford [88]. Briefly, $100 \mu \mathrm{L}$ sample was mixed with $5 \mathrm{~mL}$ Bradford reagent SigmaAldrich (St. Louis, MO, USA). After $5 \mathrm{~min}$, the absorbance was measured in the wavelength of $595 \mathrm{~nm}$ in a Spectrophotometer model Thermo Scientific ${ }^{\mathrm{TM}}$ GENESYS 10S UV-Vis (Waltham, MA, USA). Protein content was estimated by means of a calibration curve obtained using concentrations of 0.05 to $1 \mathrm{mg} \mathrm{mL}^{-1}$ of Bovine Serum Albumin from Sigma-Aldrich (St. Louis, MO, USA).

\subsubsection{SDS-PAGE Analysis}

The electrophoresis analyzes of A. japonicus extracts performed based on the methodology described by Laemmli [89]. The gel was prepared with $12 \%$ polyacrylamide by applying $30 \mu \mathrm{L}$ of the sample ate the concentrations $155.2 \mathrm{mg} \mathrm{mL}^{-1}$ and $257.2 \mathrm{mg} \mathrm{mL}^{-1}$ and 14.4-97.0 kDa molecular weight marker BluEYE Sigma-Aldrich (St. Louis, MO, USA).

\subsubsection{Lipase Immobilization Using Different Supports}

The immobilizations of microbial lipase on different supports, namely diatomite, vermiculite, montmorillonite KSF and kaolinite, were performed based on the methodology described by Vescovi et al. [14]. For that, $1 \mathrm{~g}$ of each support was suspended in $25 \mathrm{~mL}$ of enzyme solution $\left(20 \mathrm{mg} \mathrm{mL} \mathrm{m}^{-1}\right.$ of protein prepared in $25 \mathrm{mM}$ sodium phosphate buffer at $\mathrm{pH}$ 7.0). The suspension was kept under mild stirring in a roller Shaker Quimis (Diadema, SP, Brazil) for $24 \mathrm{~h}$, at $25^{\circ} \mathrm{C}$. After that, the solution was centrifuged at $8161 \times g$ in centrifuge Eppendorf model $5415 \mathrm{D}$ (Hamburg, Germany) for 5 min, to separate derivates, followed in the supernatant was determined the hydrolytic activity and the protein content, according methodologies described at Sections 3.4.1 and 3.4.2, respectively. The immobilization yield $(n, \%)$ was calculated according to the Equation (1):

$$
N=100-((\mathrm{P} \times 100) / \mathrm{Po})
$$

where: $\mathrm{P}=$ Protein content of immobilized derivative supernatant; $\mathrm{Po}=$ Protein content absorbance in time 0 .

\subsection{Characterization of Free and Immobilized Microbial Lipase}

\subsubsection{Determination of Optimum $\mathrm{pH}$ and Temperature}

In order to evaluate the optimal $\mathrm{pH}$ of the enzyme, the hydrolytic lipase assay was carried out at different $\mathrm{pH}$ values (from 3.0 to 10.0 ) using different buffers at $0.1 \mathrm{M}$ : Mcllvaine buffer ( $\mathrm{pH} 3.0$ to 6.0), phosphate buffer ( $\mathrm{pH} 7.0$ and 8.0) and carbonate bicarbonate Buffer ( $\mathrm{pH} 9.0$ to 10.0). These experiments were performed at $30^{\circ} \mathrm{C}$. The optimal temperature was determined in the optimum $\mathrm{pH} 8.0$ and it was calculated using a hydrolytic lipase activity incubated in the temperature ranged from 20 to $60^{\circ} \mathrm{C}$, in a thermostatic bath New Ethics model 521/2DE (New Ethics, Piracicaba, Brazil).

\subsubsection{Determination of Kinetic Parameters}

The influence of olive oil substrate concentration on the initial hydrolysis activity of A. japonicus lipase (free or immobilized), was evaluated under the optimum $\mathrm{pH}$ and temperature conditions of the reaction $\left(30^{\circ} \mathrm{C}, \mathrm{pH} 8,200 \mathrm{rpm}\right.$ at $\left.5 \mathrm{~min}\right)$. Since olive oil 
concentration lower than $186 \mathrm{mmol}$ did not generate a stable emulsion, the kinetic studies were performed varying the olive oil substrate from 186 to $2604 \mathrm{mmol}$, i.e, 5 to $70 \% \mathrm{w} \mathrm{w}^{-1}$. For this relation (mmol in $\% \mathrm{w} \mathrm{w}^{-1}$ ), the average molar mass of olive oil of $1344 \mathrm{~g} \mathrm{~mol}^{-1}$ was considered, based on its fatty acid composition. The kinetic constant: MichaelisMenten constant $\left(K_{M}\right)$ and specific enzyme activity $\left(V_{\text {max }}\right)$ were calculated from the data obtained experimentally with the equation of Michaelis-Menten using software Origin 8.0 OriginLab (serial GA3S5-6089-7173339, USA).

\subsubsection{Stability of the Free and Immobilized Microbial Lipase}

For $\mathrm{pH}$ stability, the enzymatic extract $(1 \mathrm{~mL})$ or immobilized derivative $(0.05 \mathrm{~g})$ were incubated in a thermostatic bath at $30{ }^{\circ} \mathrm{C}, \mathrm{pH}$ from 4.0 to 9.0 for $12 \mathrm{~h}$. In the case of temperature stability, the enzymatic extract $(1 \mathrm{~mL})$ or immobilized derivative $(0.05 \mathrm{~g})$ were also incubated in a thermostatic bath at $20^{\circ} \mathrm{C}, 30^{\circ} \mathrm{C}, 40^{\circ} \mathrm{C}$ and $50{ }^{\circ} \mathrm{C}$, in optimal pH for $12 \mathrm{~h}$. In both cases, the residual hydrolytic activity of lipase was determined after $0,2,4,6$ and $12 \mathrm{~h}$ according to methodology described at Section 3.4.1.

For the stability assays, the relative activity (RA, \%) of lipase from A. japonicus lipase immobilized by physical adsorption were calculated according to the Equation (2):

$$
\mathrm{RA}=\left(\mathrm{L}_{\mathrm{A}} \times 100\right) / \mathrm{L}_{\mathrm{A} 0}
$$

where: $\mathrm{L}_{\mathrm{A}}$ is the free/immobilized lipase activity after the incubation time and $\mathrm{L}_{\mathrm{A} 0}$ initial enzymatic activity.

\section{Conclusions}

In this work, the immobilization process of lipase produced by $A$. japonicus using clays as support was studied. The lipase immobilized in MSKF showed the more promising results comparing to the other supports evaluated achieving immobilization yield and hydrolytic activity of $69.47 \%$ and $270.7 \mathrm{U} \mathrm{g}^{-1}$, respectively. Comparing the catalytic performance of enzyme immobilized and free, the immobilization process improved the lipase stability regarding temperature and $\mathrm{pH}$ and promoted an increment in the enzymesubstrate affinity since the value of $V_{M A X}$ increased compared to the free one while the value of $K_{M}$ decreased. These findings shows that the lipase immobilization on clay support creates a good synergetic able to improve the lipase catalytic performance being an interest purpose to apply in lipases with industrial interests.

Author Contributions: D.R. conceived and designed the experiments, performed the experiments, analyzed the data, contributed reagents/materials/analysis tools, prepared figures and/or tables, authored or reviewed drafts of the paper, approved the final draft. B.R.F. conceived and designed the experiments, performed the experiments, analyzed the data. J.C.B. conceived and designed the experiments, analyzed the data, authored or reviewed drafts of the paper, approved the final draft. C.U.M. analyzed the data, authored or reviewed drafts of the paper, approved the final draft. V.d.C.S.-E. conceived and designed the experiments, performed the experiments, analyzed the data, contributed reagents/materials/analysis tools, prepared figures and/or tables, authored or reviewed drafts of the paper, approved the final draft. A.V.d.P. conceived and designed the experiments, performed the experiments, analyzed the data, contributed reagents/materials/analysis tools, prepared figures and/or tables, authored or reviewed drafts of the paper, approved the final draft. All authors have read and agreed to the published version of the manuscript.

Funding: This study was financed in part by the Coordenação de Aperfeiçoamento de Pessoal de Nível Superior-Brasil (CAPES), Fundação de Amparo à Pesquisa do Estado de São Paulo FAPESP (Process 2017/11482-7, 2018/06908-8, 2019/15493-9, 2020/09592-1 and 2020/08655-0), and Conselho Nacional de Desenvolvimento Científico e Tecnológico CNPq.

Acknowledgments: Maria Francisca Simas Teixeira that provided the microorganism from the Culture Collection of Federal University of Amazonas, DPUA, AM, Brazil.

Conflicts of Interest: The authors declare no conflict of interest. 


\section{References}

1. Seddigi, Z.S.; Malik, M.S.; Ahmed, S.A.; Babalghith, A.O.; Kamal, A. Lipases in asymmetric transformations: Recent advances in classical kinetic resolution and lipase-metal combinations for dynamic processes. Coord. Chem. Rev. 2017, 348, 54-70. [CrossRef]

2. Sankar, S.; Ponnuraj, K. Less explored plant lipases: Modeling and molecular dynamics simulations of plant lipases in different solvents and temperatures to understand structure-function relationship. Int. J. Biol. Macromol. 2020, 164, 3546-3558. [CrossRef]

3. Chandra, P.; Enespa; Singh, R.; Arora, P.K. Microbial lipases and their industrial applications: A comprehensive review. Microb. Cell Fact. 2020, 19, 169. [CrossRef]

4. Rafiee, F.; Rezaee, M. Different strategies for the lipase immobilization on the chitosan based supports and their applications. Int. J. Biol. Macromol. 2021, 179, 170-195. [CrossRef]

5. Microbial Lipase Market-Growth, Trends and Forecasts (2018-2023). Available online: https:/ /www.marketsandmarkets.com/ Market-Reports/microbial-lipase-market-248464055.html (accessed on 9 August 2021).

6. Geoffry, K.; Achur, R.N. Screening and production of lipase from fungal organisms. Biocatal. Agric. Biotechnol. 2018, 14, 241-253. [CrossRef]

7. Pandey, N.; Dhakar, K.; Jain, R.; Pandey, A. Temperature dependent lipase production from cold and pH tolerant species of Penicillium. Mycosphere 2016, 7, 1533-1545. [CrossRef]

8. Meghwanshi, G.K.; Vashishtha, A. Biotechnology of fungal lipases. In Fungi and Their Role in Sustainable Development: Current Perspectives; Gehlot, P., Singh, J., Eds.; Springer: Singapore, 2018; pp. 383-411. ISBN 9789811303937.

9. Basheer, S.M.; Chellappan, S.; Beena, P.; Sukumaran, R.K.; Elyas, K.; Chandrasekaran, M. Lipase from marine Aspergillus awamori BTMFW032: Production, partial purification and application in oil effluent treatment. New Biotechnol. 2011, 28, 627-638. [CrossRef]

10. Melani, N.; Tambourgi, E.B.; Silveira, E. Lipases: From Production to Applications. Sep. Purif. Rev. 2020, 49, 143-158. [CrossRef]

11. Bharathi, D.; Rajalakshmi, G. Microbial lipases: An overview of screening, production and purification. Biocatal. Agric. Biotechnol. 2019, 22, 101368. [CrossRef]

12. Contesini, F.J.; Calzado, F.; Madeira, J.V.; Rubio, M.V.; Zubieta, M.P.; de Melo, R.R.; Gonçalves, T.A. Aspergillus Lipases: Biotechnological and Industrial Application. In Reference Series in Phytochemistry; Springer: Cham, Switzerland, 2017 ; pp. 639-666.

13. Remonatto, D.; de Oliveira, J.V.; Guisan, J.M.; de Oliveira, D.; Ninow, J.; Fernandez-Lorente, G. Production of FAME and FAEE via Alcoholysis of Sunflower Oil by Eversa Lipases Immobilized on Hydrophobic Supports. Appl. Biochem. Biotechnol. 2018, 185, 705-716. [CrossRef]

14. Vescovi, V.; Kopp, W.; Guisán, J.M.; Giordano, R.L.; Mendes, A.A.; Tardioli, P.W. Improved catalytic properties of Candida antarctica lipase B multi-attached on tailor-made hydrophobic silica containing octyl and multifunctional amino- glutaraldehyde spacer arms. Process. Biochem. 2016, 51, 2055-2066. [CrossRef]

15. Virgen-Ortíz, J.J.; Pascacio, V.G.T.; Hirata, D.B.; Torrestiana-Sanchez, B.; Rosales-Quintero, A.; Fernandez-Lafuente, R. Relevance of substrates and products on the desorption of lipases physically adsorbed on hydrophobic supports. Enzym. Microb. Technol. 2017, 96, 30-35. [CrossRef] [PubMed]

16. Guisan, J.M.; López-Gallego, F.; Bolivar, J.M.; Rocha-Martín, J.; Fernandez-Lorente, G. The Science of Enzyme Immobilization. In Methods in Molecular Biology; Guisan, J., Bolivar, J., López-Gallego, F., Rocha-Martín, J., Eds.; Publisher: Humana, NY, USA, 2020; Volume 2100, pp. 1-26. [CrossRef]

17. Liu, J.; Ma, R.-T.; Shi, Y.-P. “Recent advances on support materials for lipase immobilization and applicability as biocatalysts in inhibitors screening methods"-A review. Anal. Chim. Acta 2020, 1101, 9-22. [CrossRef]

18. Etcheverry, M.; Cappa, V.; Trelles, J.; Zanini, G. Montmorillonite-alginate beads: Natural mineral and biopolymers based sorbent of paraquat herbicides. J. Environ. Chem. Eng. 2017, 5, 5868-5875. [CrossRef]

19. Ashkan, Z.; Hemmati, R.; Homaei, A.; Dinari, A.; Jamlidoost, M.; Tashakor, A. Immobilization of enzymes on nanoinorganic support materials: An update. Int. J. Biol. Macromol. 2021, 168, 708-721. [CrossRef] [PubMed]

20. Cecilia, J.A.; Jiménez-Gómez, C.P. Catalytic Applications of Clay Minerals and Hydrotalcites. Catalysts 2021, 11, 68. [CrossRef]

21. Naik, S.; Scholin, J.; Goss, B. Stabilization of phytase enzyme on montmorillonite clay. J. Porous Mater. 2016, 23, 401-406. [CrossRef]

22. Viana, A.C.; Ramos, I.G.; Mascarenhas, A.J.S.; dos Santos, E.L.; Sant'Ana, A.E.G.; Goulart, H.F.; Druzian, J.I. Release of aggregation pheromone rhynchophorol from clay minerals montmorillonite and kaolinite. J. Therm. Anal. Calorim. 2021, 1, 1-13. [CrossRef]

23. Tanasković, S.J.; Jokić, B.; Grbavčić, S.; Drvenica, I.; Prlainović, N.; Luković, N.; Knežević-Jugović, Z. Immobilization of Candida antarctica lipase B on kaolin and its application in synthesis of lipophilic antioxidants. Appl. Clay Sci. 2017, 135, 103-111. [CrossRef]

24. Pereira, F.A.; Sousa, K.S.; Cavalcanti, G.R.; França, D.B.; Queiroga, L.N.; dos Santos, I.M.G.; Fonseca, M.; Jaber, M. Green biosorbents based on chitosan-montmorillonite beads for anionic dye removal. J. Environ. Chem. Eng. 2017, 5, 3309-3318. [CrossRef]

25. Długosz, O.; Banach, M. Kinetic, isotherm and thermodynamic investigations of the adsorption of Ag+ and Cu2+ on vermiculite. J. Mol. Liq. 2018, 258, 295-309. [CrossRef]

26. Mohammadi, M.; Heshmati, M.K.; Sarabandi, K.; Fathi, M.; Lim, L.-T.; Hamishehkar, H. Activated alginate-montmorillonite beads as an efficient carrier for pectinase immobilization. Int. J. Biol. Macromol. 2019, 137, 253-260. [CrossRef] [PubMed]

27. Zhao, Y.; Tian, G.; Duan, X.; Liang, X.; Meng, J.; Liang, J. Environmental Applications of Diatomite Minerals in Removing Heavy Metals from Water. Ind. Eng. Chem. Res. 2019, 58, 11638-11652. [CrossRef] 
28. Brião, G.D.V.; da Silva, M.G.C.; Vieira, M.G.A. Efficient and Selective Adsorption of Neodymium on Expanded Vermiculite. Ind. Eng. Chem. Res. 2021, 60, 4962-4974. [CrossRef]

29. Song, X.; Li, C.; Chai, Z.; Zhu, Y.; Yang, Y.; Chen, M.; Ma, R.; Liang, X.; Wu, J. Application of diatomite for gallic acid removal from molasses wastewater. Sci. Total Environ. 2021, 765, 142711. [CrossRef]

30. Vallova, S.; Plevova, E.; Smutna, K.; Sokolova, B.; Vaculikova, L.; Valovicova, V.; Hundakova, M.; Praus, P. Removal of analgesics from aqueous solutions onto montmorillonite KSF. J. Therm. Anal. Calorim. 2021, 1, 1-9. [CrossRef]

31. Yu, W.H.; Li, N.; Tong, D.S.; Zhou, C.H.; Lin, C.X.; Xu, C.Y. Adsorption of proteins and nucleic acids on clay minerals and their interactions: A review. Appl. Clay Sci. 2013, 80-81, 443-452. [CrossRef]

32. Szabó, T.; Mitea, R.; Leeman, H.; Premachandra, G.S.; Johnston, C.T.; Szekeres, M.; Dékány, I.; Schoonheydt, R.A. Adsorption of protamine and papain proteins on saponite. Clays Clay Miner. 2008, 56, 494-504. [CrossRef]

33. Sanjay, G.; Sugunan, S. Enhanced pH and thermal stabilities of invertase immobilized on montmorillonite K-10. Food Chem. 2006, 94, 573-579. [CrossRef]

34. Gopinath, S.; Sugunan, S. Enzymes immobilized on montmorillonite K 10: Effect of adsorption and grafting on the surface properties and the enzyme activity. Appl. Clay Sci. 2007, 35, 67-75. [CrossRef]

35. Dong, H.; Li, Y.; Li, J.; Sheng, G.; Chen, H. Comparative Study on Lipases Immobilized onto Bentonite and Modified Bentonites and Their Catalytic Properties. Ind. Eng. Chem. Res. 2013, 52, 9030-9037. [CrossRef]

36. Da Silva, V.C.F.; Contesini, F.; Carvalho, P.D.O. Enantioselective behavior of lipases from Aspergillus niger immobilized in different supports. J. Ind. Microbiol. Biotechnol. 2009, 36, 949-954. [CrossRef] [PubMed]

37. Benamia, F.; Benouis, S.; Belafriekh, A.; Semache, N.; Rebbani, N.; Djeghaba, Z. Efficient Candida rugosa lipase immobilization on Maghnite clay and application for the production of (1R)-(-)-Menthyl acetate. Chem. Pap. 2017, 71, 785-793. [CrossRef]

38. Scherer, R.P.; Dallago, R.L.; Penna, F.G.; Bertella, F.; de Oliveira, D.; de Oliveira, J.V.; Pergher, S.B. Influence of process parameters on the immobilization of commercial porcine pancreatic lipase using three low-cost supports. Biocatal. Agric. Biotechnol. 2012, 1, 290-294. [CrossRef]

39. Babavatan, E.O.; Yildirim, D.; Peksel, A.; Binay, B. Immobilization ofRhizomucor mieheilipase onto montmorillonite K-10 and polyvinyl alcohol gel. Biocatal. Biotransform. 2019, 38, 1-9. [CrossRef]

40. Tu, N.; Shou, J.; Dong, H.; Huang, J.; Li, Y. Improved Catalytic Performance of Lipase Supported on Clay/Chitosan Composite Beads. Catalysts 2017, 7, 302. [CrossRef]

41. Zou, T.; Duan, Y.-D.; Wang, Q.-E.; Cheng, H.-M. Preparation of Immobilized Lipase on Silica Clay as a Potential Biocatalyst on Synthesis of Biodiesel. Catalysts 2020, 10, 1266. [CrossRef]

42. Coghetto, C.C.; Scherer, R.P.; Silva, M.F.; Golunski, S.; Pergher, S.; Oliveira, D.; Oliveira, J.V.; Treichel, H. Natural montmorillonite as support for the immobilization of inulinase from Kluyveromyces marxianus NRRL Y-7571. Biocatal. Agric. Biotechnol. 2012, 1, 284-289. [CrossRef]

43. Contesini, F.J.; Lopes, D.B.; Macedo, G.; Nascimento, M.D.G.; de Carvalho, P. Aspergillus sp. lipase: Potential biocatalyst for industrial use. J. Mol. Catal. B Enzym. 2010, 67, 163-171. [CrossRef]

44. Sita, K.K.; Narasimha, R.M.; Karanam, S.K.; Medicherla, N.R. Enhanced lipase production by mutation induced Aspergillus japonicus. Afr. J. Biotechnol. 2008, 7, 2064-2067. [CrossRef]

45. Bharti, M.K.; Khokhar, D.; Pandey, A.K.; Gaur, A.K. Purification and Characterization of Lipase from Aspergillus japonicas: A Potent Enzyme for Biodiesel Production. Natl. Acad. Sci. Lett. 2013, 36, 151-156. [CrossRef]

46. Sobha, K.; Lalitha, N.; Pavani, N.; Praharshini, R.; Pradeep, D. Statistical optimization of Factors influencing the activity and the kinetics of partially purified Lipase produced from Aspergillus japonicus (MTCC 1975) cultured in protein enriched medium. Int. J. Chem. Tech. Res. 2014, 6, 4817-4831.

47. Souza, L.T.A.; Oliveira, J.S.; Dos Santos, V.L.; Régis, W.C.B.; Santoro, M.M.; Resende, R.R. Lipolytic Potential of Aspergillus japonicus LAB01: Production, Partial Purification, and Characterisation of an Extracellular Lipase. BioMed Res. Int. 2014, 1-11. [CrossRef]

48. Jayaprakash, A.; Ebenezer, P. Optimization of Aspergillus japonicus lipase production by Response Surface Methodology. J. Acad. Ind. Res. 2012, 1, 23-30.

49. Jayaprakash, A.; Ebenezer, P. Investigation on extracellular lipase production by Aspergillus japonicus isolated from the paper nest of Ropalidia marginata. Indian J. Sci. Technol. 2010, 3, 113-117. [CrossRef]

50. Rani, N.V.K.M.E.; Kannan, R.R.G.N.D. Lipase Production using Aspergillus japonicus MF-1 through Biotransformation of AgroWaste and Medicinal Oil Effluent. Int. J. Curr. Microbiol. Appl. Sci. 2017, 6, 2005-2020. [CrossRef]

51. Colla, L.M.; Ficanha, A.M.M.; Rizzardi, J.; Bertolin, T.E.; Reinehr, C.; Costa, J.A.V. Production and Characterization of Lipases by Two New Isolates of Aspergillus through Solid-State and Submerged Fermentation. BioMed Res. Int. 2015, 1-9. [CrossRef]

52. Jyoti, G.; Keshav, A.; Anandkumar, J. Review on Pervaporation: Theory, Membrane Performance, and Application to Intensification of Esterification Reaction. J. Eng. 2015, 2015, 1-24. [CrossRef]

53. Sharma, R.; Soni, S.; Vohra, R.; Gupta, L.; Gupta, J. Purification and characterisation of a thermostable alkaline lipase from a new thermophilic Bacillus sp. RSJ-1. Process. Biochem. 2002, 37, 1075-1084. [CrossRef]

54. Tacin, M.V.; Massi, F.P.; Fungaro, M.H.P.; Teixeira, M.F.S.; de Paula, A.V.; Santos-Ebinuma, V. Biotechnological valorization of oils from agro-industrial wastes to produce lipase using Aspergillus sp. from Amazon. Biocatal. Agric. Biotechnol. 2019, 17, 369-378. [CrossRef] 
55. Mandari, V.; Nema, A.; Devarai, S.K. Sequential optimization and large scale production of lipase using tri-substrate mixture from Aspergillus niger MTCC 872 by solid state fermentation. Process. Biochem. 2020, 89, 46-54. [CrossRef]

56. Utami, T.S.; Hariyani, I.; Alamsyah, G.; Hermansyah, H. Production of dry extract extracellular lipase from Aspergillus niger by solid state fermentation method to catalyze biodiesel synthesis. Energy Procedia 2017, 136, 41-46. [CrossRef]

57. Das, A.; Shivakumar, S.; Bhattacharya, S.; Shakya, S.; Swathi, S.S. Purification and characterization of a surfactant-compatible lipase from Aspergillus tamarii JGIF06 exhibiting energy-efficient removal of oil stains from polycotton fabric. 3 Biotech 2016, 6, 131. [CrossRef]

58. Saxena, R.; Davidson, W.; Sheoran, A.; Giri, B. Purification and characterization of an alkaline thermostable lipase from Aspergillus carneus. Process. Biochem. 2003, 39, 239-247. [CrossRef]

59. Gomes, F.M.; De Paula, A.V.; Silva, G.D.S.; De Castro, H.F. Determinação das propriedades catalíticas em meio aquoso e orgânico da lipase de Candida rugosa imobilizada em celulignina quimicamente modificada por carbonildiimidazol. Química Nova 2006, 29, 710-718. [CrossRef]

60. Mala, J.G.S.; Takeuchi, S. Understanding Structural Features of Microbial Lipases-An Overview. Anal. Chem. Insights 2008, 3, ACI.S551-19. [CrossRef]

61. An, N.; Zhou, C.H.; Zhuang, X.Y.; Tong, D.S.; Yu, W.H. Immobilization of enzymes on clay minerals for biocatalysts and biosensors. Appl. Clay Sci. 2015, 114, 283-296. [CrossRef]

62. Quiquampoix, H.; Staunton, S.; Baron, M.-H.; Ratcliffe, R.G. Interpretation of the $\mathrm{pH}$ dependence of protein adsorption on clay mineral surfaces and its relevance to the understanding of extracellular enzyme activity in soil. Colloids Surf. A Physicochem. Eng. Asp. 1993, 75, 85-93. [CrossRef]

63. De Oliveira, M.F.; Johnston, C.T.; Premachandra, G.S.; Teppen, B.J.; Li, H.; Laird, D.A.; Zhu, D.; Boyd, S.A. Spectroscopic Study of Carbaryl Sorption on Smectite from Aqueous Suspension. Environ. Sci. Technol. 2005, 39, 9123-9129. [CrossRef] [PubMed]

64. Basso, A.; Froment, L.; Hesseler, M.; Serban, S. New highly robust divinyl benzene/acrylate polymer for immobilization of lipase CALB. Eur. J. Lipid Sci. Technol. 2013, 115, 468-472. [CrossRef]

65. Basso, A.; Hesseler, M.; Serban, S. Hydrophobic microenvironment optimization for efficient immobilization of lipases on octadecyl functionalised resins. Tetrahedron 2016, 72, 7323-7328. [CrossRef]

66. Lorente, F.; Cabrera, Z.; Godoy, C.; Fernandez-Lafuente, R.; Palomo, J.M.; Guisan, J.M. Interfacially activated lipases against hydrophobic supports: Effect of the support nature on the biocatalytic properties. Process. Biochem. 2008, 43, 1061-1067. [CrossRef]

67. Sani, F.; Mokhtar, N.F.; Shukuri, M.; Ali, M.; Noor, R.; Raja, Z.; Rahman, A. Enhanced Performance of Immobilized Rhizopus oryzae Lipase on Coated Porous Polypropylene Support with Additives. Catalysts 2021, 11, 303. [CrossRef]

68. Mulinari, J.; Oliveira, J.V.; Hotza, D. Lipase immobilization on ceramic supports: An overview on techniques and materials. Biotechnol. Adv. 2020, 42, 107581. [CrossRef] [PubMed]

69. Jaeger, K.E.; Reetz, M.T. Microbial lipases form versatile tools for biotechnology. Trends Biotechnol. 1998, 16, 396-403. [CrossRef]

70. Khan, F.I.; Lan, D.; Durrani, R.; Huan, W.; Zhao, Z.; Wang, Y. The Lid Domain in Lipases: Structural and Functional Determinant of Enzymatic Properties. Front. Bioeng. Biotechnol. 2017, 5, 16. [CrossRef] [PubMed]

71. Lai, O.-M.; Lee, Y.Y.; Phuah, E.-T.; Akoh, C.C. Lipase/Esterase: Properties and Industrial Applications. In Encyclopedia of Food Chemistry; Melton, L., Shahidi, F., Varelis, P., Eds.; Academia Press: Waltham, MA, USA, 2019; pp. $158-167$.

72. Nascimento, P.A.M.; Picheli, F.P.; Lopes, A.; Pereira, J.F.B.; Santos-Ebinuma, V.D.C. Effects of cholinium-based ionic liquids on Aspergillus niger lipase: Stabilizers or inhibitors. Biotechnol. Prog. 2019, 35, e2838. [CrossRef] [PubMed]

73. Palomo, J.M.; Muñoz, G.; Lorente, F.; Mateo, C.; Fernández-Lafuente, R.; Guisán, J.M. Interfacial adsorption of lipases on very hydrophobic support (octadecyl-Sepabeads): Immobilization, hyperactivation and stabilization of the open form of lipases. $J$. Mol. Catal. B Enzym. 2002, 19-20, 279-286. [CrossRef]

74. Fernandez-Lafuente, R.; Armisén, P.; Sabuquillo, P.; Lorente, F.; Guisán, J.M. Immobilization of lipases by selective adsorption on hydrophobic supports. Chem. Phys. Lipids 1998, 93, 185-197. [CrossRef]

75. Bastida, A.; Sabuquillo, P.; Armisen, P.; Fernández-Lafuente, R.; Huguet, J.; Guisán, J.M. A Single Step Purification, Immobilization, and Hyperactivation of Lipases via Interfacial Adsorption on Strongly Hydrophobic Supports. Biotechnol. Bioeng. 1998, 58, 486-493. [CrossRef]

76. Tacin, M.V.; Costa-Silva, T.A.; de Paula, A.V.; Palomo, J.M.; Santos-Ebinuma, V.D.C. Microbial lipase: A new approach for a heterogeneous biocatalyst. Prep. Biochem. Biotechnol. 2021, 51, 749-760. [CrossRef]

77. Wu, C.; Zhou, G.; Jiang, X.; Ma, J.; Zhang, H.; Song, H. Active biocatalysts based on Candida rugosa lipase immobilized in vesicular silica. Process. Biochem. 2012, 47, 953-959. [CrossRef]

78. Balcão, V.; Paiva, A.L.; Malcata, F. Bioreactors with immobilized lipases: State of the art. Enzym. Microb. Technol. 1996, 18, 392-416. [CrossRef]

79. Tang, A.; Zhang, Y.; Wei, T.; Wu, J.; Li, Q.; Liu, Y. Immobilization of Candida cylindracea Lipase by Covalent Attachment on Glu-Modified Bentonite. Appl. Biochem. Biotechnol. 2018, 187, 870-883. [CrossRef]

80. Zhao, Z.; Hou, S.; Lan, D.; Wang, X.; Liu, J.; Khan, F.I.; Wang, Y. Crystal structure of a lipase from Streptomyces sp. strain W007-Implications for thermostability and regiospecificity. FEBS J. 2017, 284, 3506-3519. [CrossRef]

81. Lozzi, I.; Calamai, L.; Fusi, P.; Bosetto, M.; Stotzky, G. Interaction of horseradish peroxidase with montmorillonite homoionic to $\mathrm{Na}^{+}$and $\mathrm{Ca}^{2+}$ : Effects on enzymatic activity and microbial degradation. Soil Biol. Biochem. 2001, 33, 1021-1028. [CrossRef] 
82. Sanjay, G.; Sugunan, S. Acid activated montmorillonite: An efficient immobilization support for improving reusability, storage stability and operational stability of enzymes. J. Porous Mater. 2008, 15, 359-367. [CrossRef]

83. Wang, Q.; Peng, L.; Li, G.; Zhang, P.; Li, D.; Huang, F.; Wei, Q. Activity of Laccase Immobilized on TiO2-Montmorillonite Complexes. Int. J. Mol. Sci. 2013, 14, 12520-12532. [CrossRef] [PubMed]

84. Morais, W.G., Jr.; Pacheco, T.F.; Gao, S.; Martins, P.A.; Guisán, J.M.; Caetano, N.S. 1 Sugarcane Bagasse Saccharification by Enzymatic Hydrolysis. Catalysts 2021, 11, 340. [CrossRef]

85. Carvalho, T.; Pereira, A.D.S.; Bonomo, R.C.F.; Franco, M.; Finotelli, P.V.; Amaral, P.F. Simple physical adsorption technique to immobilize Yarrowia lipolytica lipase purified by different methods on magnetic nanoparticles: Adsorption isotherms and thermodynamic approach. Int. J. Biol. Macromol. 2020, 160, 889-902. [CrossRef] [PubMed]

86. Basso, A.; Serban, S. Industrial applications of immobilized enzymes-A review. Mol. Catal. 2019, 479, 110607. [CrossRef]

87. Soares, C.M.F.; De Castro, H.F.; De Moraes, F.F.; Zanin, G.M. Characterization and utilization of Candida rugosa lipase immobilized on controlled pore silica. Appl. Biochem. Biotechnol. Part A Enzym. Eng. Biotechnol. 1999, 77-79, 745-757. [CrossRef]

88. Bradford, M.M. A rapid and sensitive method for the quantitation of microgram quantities of protein utilizing the principle of protein-dye binding. Anal. Biochem. 1976, 72, 248-254. [CrossRef]

89. Laemmli, U.K. Cleavage of Structural Proteins during the Assembly of the Head of Bacteriophage T4. Nature 1970, $227,680-685$. [CrossRef] 